\title{
Season influence on milk physico-chemical and microbiological aspects in Western Santa Catarina
}

\section{Influência da época do ano sobre a composição físico-química e microbiológica do leite na região Oeste de Santa Catarina}

\author{
Flávio José Simioni1*; Leandro Sâmia Lopes ${ }^{1}$; Cassia Regina Nespolo²; \\ Lenita Moura Stefani ${ }^{1}$; Rael Bordignon ${ }^{3}$; Mailyn Stephanee Bittelbrun ${ }^{4}$
}

\begin{abstract}
The objective of this study was to analyze the influence of seasonal changes on milk quality in Western Santa Catarina, Brazil. Dairy farms (799) had raw milk samples (9144) collected and analyzed for fat, protein, SCC (somatic cell count) and TBC (total bacterial count). Samples were collected from cooling tanks on the farm during the months of October 2009 to September 2010 and grouped into four seasons (summer, autumn, winter, and spring). The data were classified according to the normative instructions 51 and 62 the Ministry of Agriculture, Livestock and Food Supply, and also according to a quality pay system adopted by the dairy industry in the region of the study. The results revealed differences between groups $(\mathrm{P}<0.05)$, where fat content was higher in autumn, protein and TBC were higher in winter and SCC showed the highest rates in the summer. According to the criteria established by legislation, the main quality problem was the TBC, with higher counts in the winter, and in the summer we observed the highest percentage of non-compliant samples. For the quality payment system, chemical composition resulted on better prices to be paid to producers, while TBC was primarily responsible lower price.
\end{abstract}

Key words: Milk quality, payment based on quality, seasonality

\section{Resumo}

O objetivo do trabalho foi analisar as variações sazonais da qualidade do leite no oeste de Santa Catarina de acordo com as estações do ano. Utilizaram-se dados de 799 produtores de leite de uma cooperativa do Oeste Catarinense, considerando os teores de gordura, proteína, CCS (contagem de células somáticas) e CBT (contagem bacteriana total) de 9144 amostras de leite cru, coletadas diretamente dos tanques de resfriamento do produtor, durante os meses de outubro de 2009 a setembro de 2010. Os dados foram agrupados em quatro estações do ano (verão, outono, inverno e primavera). Para as quatro estações do ano, os dados também foram classificados segundo as instruções normativas IN 51 e IN 62 do Ministério da Agricultura, Pecuária e Abastecimento, como também de acordo com um sistema de remuneração ao produtor adotado por laticínios na região do estudo. Os resultados revelaram diferença entre os grupos $(\mathrm{P}<0.05)$, sendo que o teor de gordura foi maior no outono, a proteína e CBT foram maiores no inverno e CCS apresentou os maiores índices no verão. Conforme os critérios estabelecidos pela legislação, o principal problema observado foi associado a CBT, sendo que no inverno foram observadas as maiores contagens e, no verão, a maior porcentagem de amostras fora do padrão preconizado pela legislação. Com base na remuneração por qualidade, a composição centesimal resultou para a maioria dos produtores em bonificação no preço do leite pago ao produtor, e a CBT foi a principal responsável pela diminuição do preço final.

Palavras-chave: Qualidade do leite, remuneração por qualidade, sazonalidade

\footnotetext{
${ }^{1}$ Profs., Universidade do Estado de Santa Catarina, UDESC, Chapecó, SC, Brasil. E-mail: flavio.simioni@udesc.br; leandrosamia@, uol.com.br; borrucia@hotmail.com

2 Prof ${ }^{a}$ de Ciência e Tecnologia de Alimentos, UNIPAMPA, Itaqui, RS, Brasil. E-mail: cnespolo@yahoo.com.br

3 Zootecnista, Técnico em Originação de Leite, BRF, Brasil Foods S.A. Chapecó, SC, Brasil. E-mail: raelbordignon@yahoo.com.br

${ }^{4}$ Discente do Curso de Engenharia de Alimentos, UDESC, Pinhalzinho, SC, Brasil. E-mail: mailynstephanee@gmail.com

* Author for correspondence
} 


\section{Introduction}

The dairy business is booming in the Western Santa Catarina, Brazil, constituting a major source of income to farmers. According to the IBGE (2010), Santa Catarina State produced in 2008 approximately 2.13 billion liters of milk and the West of Santa Catarina was responsible for $72.4 \%$. In 2010 milk production increased to 2.38 billion liters, of which 1.7 billion liters was from the West region, which represents an increase of almost $12 \%$.

According to Santos et al. (2001), the state of Santa Catarina is in a process of specialization and professionalization of milk production since 1990's, despite a reduction in the number of producers. After a decade, the IBGE (2010) confirm this trend, since the number of milk producers in Santa Catarina reduced from 145 thousand in 1995/96 to approximately 89 thousand in 2006. Quantitative increase on milk production indicates a significant growth in production; however there are doubts regarding its quality. According to Fonseca and Santos (2000), a decrease of $0.5 \%$ on milk total solids, means a loss of up to five tons of powdered milk for every million liters of processed milk. With a increasing concern for milk quality, the dairy market in Brazil pays attention not only to quantitative parameters. In this scenario, the industries have encouraged producers to participate to a quality payment system according to milk quality, by monitoring properties with proper technical assistance and training on good manufacturing practices.

According to Ribas et al. (2004), the composition of bovine milk varies according to several factors: herd, region, year, month, storage time after sampling, and somatic cell count (SCC). Some studies conducted in different parts of the world have evaluated the effect of seasonal variations on milk quality. In the Brazilian Amazon region, density, temperature, and acidity Dornic were significantly affected during the dry or rainy seasons, and the fat, protein and dry matter did not vary (GOMES et al., 2011). Seasonal changes in SCC were observed in a study performed with bovine milk in Iran, where increased counts were observed during spring and summer time (NAJAFI et al., 2009), in contrast to a study performed in UK that did not find SCC increase during summer (GREEN et al., 2006).

Several studies have been conducted with the objective to verify compliance to a new legislation set by the Brazilian Government called Normative Instruction 51 (IN 51) (BRASIL, 2002) and later by IN 62 (BRASIL, 2011) that have set new standards to ensure milk quality A study in Santa Catarina prior to the publication of IN 62 already indicated that milk producers had no knowledge about proper standards of milk quality and had difficulties on meeting new standards implemented by legislation (WINCK; THALER NETO, 2009). The monitoring of milk quality implemented by several dairies in the country allowed the creation of databases with valuable information about seasonal variations that influence the solids and competitiveness even in front of the international markets (PAIVA et al., 2012). As a consequence, analysis of information generated could help in the development of policies for improving the quality of milk in the country and its equivalence to the international market, allowing milk to obtain a higher quality and also an income increase to producers adjusted to these new requirements.

Given the above, the aim of this study was to evaluate fat, protein, SCC and TBC in milk from the West part of Santa Catarina State, according to the season of production. Also, to check the proportion of samples considered appropriate under the law and the expected impact on the price paid to producers considering a payment program for quality practiced in Western of Santa Catarina State.

\section{Material and Methods}

The experiment was conducted in the Animal Science Department of the University of Santa Catarina State - Chapecó Center, from one database of 799 milk production units of Concórdia 
Cooperative (Coopérdia) located in the West Region of Santa Catarina State, in a subregion called High Uruguay. In this region, the climate is mesothermal, with annual average temperature of about $20{ }^{\circ} \mathrm{C}$ and middle annual precipitation above $2000 \mathrm{~mm}$, distributed throughout the year (OMETTO, 1981) and average temperature of $23.0{ }^{\circ} \mathrm{C}$ in summer, $18.6^{\circ} \mathrm{C}$ in autumn, $14.2{ }^{\circ} \mathrm{C}$ in winter and $19.0^{\circ} \mathrm{C}$ in the spring (EPAGRI/CIRAM). Family farming is prevalent and dairy herds are composed mainly by animal from Holland breed and secondarily by Jersey, where pastures consist mainly of temperate grasses of Cynodon sp. all year long and other grasses such as oatmeal and rye grass in the winter period.

Milk samples were taken directly from the cooling tank of every producer, every month during the period October 2009 to September 2010, totaling 9.144 samples. The collection procedure was performed by the cooperative, following the protocol recommended by the Ministry of Agriculture, Livestock and Supply of Brazil (BRASIL, 2009). The samples were submitted in sterile containers and refrigerated to the laboratory of the State Center of Research and Diagnostics in Food (UNC/CIDASC - Concórdia/SC).

To evaluate milk quality, the physical and chemical composition of milk (fat, protein and SCC) and microbiological (TBC) was considered. The percentage contents of fat and protein were determined by NIRS (MIR Model 2000, Bentley Instruments) according to the methodology described by IDF (2000). The TBC was measured in $\mathrm{CFU} / \mathrm{mL}$ by flow cytometric (Model IBC, Bentley Instruments) (IDF, 2004) and the SCC was obtained in cells/mL also by flow cytometry (Model Somacount 300, Bentley Instruments) (IDF, 2006).

Initially, in order to reduce the influence of extreme values due to sampling errors and/or decreasing the amplitude and analytical data, samples with values that exceeded the limits of two standard deviations from the mean $(\mu \pm 2 \sigma)$ were excluded. With this procedure, the number of samples for fat, protein, SCC, and TBC reduced to $8613,8755,8764$ and 8593 , respectively.

The seasonal variation of milk quality was evaluated considering four seasons, which constituted the groups: summer (December, January and February), autumn (March, April and May), winter (June, July and August) and spring (September, October and November). The characteristics of fat, protein, SCC, and TBC were subjected to analysis of variance, in a completely randomized design where the means were compared by Tukey test with $5 \%$ probability, using the SAS statistical package (SAS INSTITUTE, 1999).

Additionally, results were compared to the standards established by Brazilian legislation for raw refrigerated milk, considering the limits applied to the period in which the samples were collected in accordance with IN 51 (BRASIL, 2002) and the current parameters of SCC and TBC, which became effective from January 2012 according to IN 62 (BRASIL, 2011).

To assess the impact on milk prices from the implementation of a payment program for quality, it was used as criteria to classify producers already adopted by another cooperative located in Western Santa Catarina. From this reference, samples were classified according to the scales of variation of fat, protein, SCC, and TBC resulting in a reduced impact, none, or additional on the price of milk paid to producers.

\section{Results and Discussion}

Results indicated that there were differences for fat and milk protein throughout the seasons $(\mathrm{P}<0.05)$. The autumn season had the highest fat content $(\mathrm{P}<0.05)$, followed by winter, spring and summer. As for the protein, the winter season showed the highest levels $(\mathrm{P}<0.05)$ followed by fall, spring and summer (Table 1). 
Table 1. Values of fat and protein $(\%)$, somatic cell count $(\mathrm{cell} / \mathrm{mL})$ and total bacterial count $(\mathrm{CFU} / \mathrm{mL})$ at different times of the year, in dairy cattle in Western Santa Catarina-Brazil.

\begin{tabular}{lcllll}
\hline \multirow{2}{*}{ Variable } & \multirow{2}{*}{ Statistics } & \multicolumn{3}{c}{ Season of the year } \\
\cline { 3 - 6 } & Average & $3,64 \mathrm{~d}$ & $4,12 \mathrm{a}$ & $4,02 \mathrm{~b}$ & $3,84 \mathrm{c}$ \\
\multirow{3}{*}{ Fat $(\%)$} & SD & 0,42 & 0,46 & 0,46 & 0,47 \\
& CV $(\%)$ & 11,42 & 11,27 & 11,56 & 12,15 \\
\hline \multirow{2}{*}{ Protein (\%) } & Average & $3,06 \mathrm{~d}$ & $3,27 \mathrm{~b}$ & $3,32 \mathrm{a}$ & $3,16 \mathrm{c}$ \\
& SD & 0,18 & 0,19 & 0,23 & 0,21 \\
& CV $(\%)$ & 5,88 & 5,78 & 7,06 & 6,50 \\
\hline \multirow{2}{*}{ SCC (thousands } & Average & $783,10 \mathrm{a}$ & $719,50 \mathrm{~b}$ & $606,25 \mathrm{c}$ & $633,19 \mathrm{c}$ \\
cells/mL) & SD & 496,41 & 447,73 & 373,20 & 395,48 \\
& CV (\%) & 63,39 & 62,23 & 61,56 & 62,46 \\
\hline \multirow{2}{*}{ TBC (thousands } & Average & $1.957,18 \mathrm{~b}$ & $1.673,71 \mathrm{c}$ & $2.383,04 \mathrm{a}$ & $1.913,05 \mathrm{~b}$ \\
UFC/mL) & SD & $1.315,53$ & $1.356,83$ & $2.850,93$ & $1.878,58$ \\
& CV (\%) & 67,22 & 81,07 & 119,63 & 98,20 \\
\hline
\end{tabular}

Means followed by the same letter do not differ significantly by Tukey test $(p<0.05)$. SD: Standard deviation Note: P-value for fat, protein, SCC and TBC $(\mathrm{p}<0,001)$.

Source: Elaboration of the authors.

The variation found for fat and protein contents in different periods of the year can be attributed mainly to different types of food consumed since the main form of milk production in the region is through the use of pastures, supplemented with corn silage and concentrated.

It is observed that the average of milk fat found was from $3.64 \%$ in the summer up to $4.12 \%$ in fall. The data obtained are similar to Machado, Pereira and Sarries (2000) with 3.61\% and Durães, Freitas and Costa (2001) with $3.50 \%$ when analyzing respectively, 4785 and 82443 milk samples in Southeastern Brazil. If we consider that, the average fat content obtained was $3.91 \%$ in this region, higher than the average found in the U.S. State of California (3.64\%), the main milk producing state in the United States (DHIA, 2001). However, the average is lower compared with other countries such as France (4.06\%) (FCL, 2000), Germany (4.19\%) (ADR, 2001), Canada (4.68\%) (FPLQ, 2000) and New Zealand (4.80\%) (NZDG, 2001).

Lower levels of fat found in milk produced during summer time can be explained by the greater need by the animal for concentrated supplementation at this time of year, since the tropical grasses, although they are more productive than temperate (higher dry matter production per area), show poor nutritional quality. Thus, many producers use concentrated feed to supplement the diet in order to explore further the productive potential of the animal and also prevent a decline in body condition of the animals, which could compromise future lactations and also the reproductive efficiency of the herd. According to Looper et al. (2001) and Ribas et al. (2004), the effect of the month or season on the solids concentration in milk may also be due to changes regarding herd handling, such as changing the relation between concentrate/roughage and dietary fiber level, frequency of feeding to minimize the effect of thermal stress, etc. However, Ribas et al. (1985) and Ribas et al. (2004) reported that addition of nutrition and genetic herd makeup, other factors such as climate, topography and soil condition can also affect the amount of milk solids.

In a study by Roma Júnior et al. (2009), the authors evaluated the bovine milk produced in the Southeast of Brazil, from October 2005 to September 2006, and the mean levels of fat were lower in most months when compared to those 
observed in the present study. The exception occurred for summer time, where a sharper decrease in fat and protein was observed. This reduction may be explained by climatic differences between the regions and the nutritional management adopted in the Southeast, where there is great use of concentrate feed almost during the entire year due to more intensive production system adopted in this region, which would contribute to the production of milk with lower fat content (BAUMAN; GRIINARI, 2003). Likewise, the milk produced in the region of Taquari Valley from August 2006 to August 2007 (BORGES et al., 2009), showed average for fat lower than observed in this study.

Another aspect to be considered is related to the variability of the data from the analysis of the coefficient of variation (CV). Minimum and maximum values obtained during the evaluated period indicate a large variation in fat content. The storage temperature for refrigerated milk and the lack of adequate homogenization at milking may lead to the separation of this fraction, which will result in very low or very high fat content, according to errors while sampling. Therefore, sampling errors may explain at least in part variation regarding fat content in milk samples. Reis et al. (2007) had already demonstrated the influence of sampling on the percentage of fat and also stressed that standardization at the time of milk collection, as well as the type of milking may affect physical and chemical constituent, as well as somatic cell count.

The highest percentages of fat and protein occurred in April to June. Roma Júnior et al. (2009) also observed higher values for fat and protein during autumn. The physico-chemical composition of milk is influenced by the dietary management of livestock, mainly bulky feeding.

These results can be explained in part for these reasons, where the highest levels of fat and protein are obtained in the months when animal feeding was based on annual winter pastures. According to González (2004) changes in the nutritional management of the herd can provide faster and economical changes in milk compared to genetic changes implemented in the herd.

In the months that milk had lower levels of fat, there is a trend towards greater use of feed concentrates as much energy as protein (corn, soybean meal, cottonseed meal, etc..), which could lead to a decrease in fat synthesis. This is the main reason for the difference found for fat content in milk when comparing animals raised on pasture to those animals receiving concentrate supplementation daily or at certain times of the year (BAUMAN; GRIINARI, 2003). According to the NRC (2001), the change in the ratio concentrate/pasture in the diet can affect in more than $15 \%$ of the fat content in milk.

When compared with pasture, concentrate feed have higher levels of lipids and unsaturated fatty acids, thus the rumen microorganisms perform biohydrogenation of fatty acids that are toxic to certain groups of rumen bacteria. This behavior, according González (2004), is known as syndrome of depression of milk fat, where the long-chain fatty acids forming part of the milk fat are altered by bacteria of the genus Butyrivibrio fibrisolvens through the rumen biohydrogenation.

The main action of trans fatty acids-10 in depression of fat is through depression of gene expression of enzymes related to lipid metabolism. According to Baumgard et al. (2002), CLA trans-10, cis-12 has the ability to depress the expression of the enzyme lipoprotein lipase gene (responsible for hydrolyzing and release of fatty acids for use by the cells), delta9-dessaturase enzyme (enzyme involved in the synthesis of monounsaturated fatty acids) and especially of the enzyme acetyl CoA carboxylase (which catalyzes the synthesis of malonyl-CoA which initiates the biosynthesis of fatty acids) by approximately $66 \%, 75 \%$ and $72 \%$, respectively.

In herds with a wide variety of breeds, such as those from the Western part of Santa Catarina State (Holstein, Jersey and animals without a 
defined breed) the variation in the levels of solids can be explained mainly by racial variation (up to $55 \%$ ) while the other $45 \%$ would be explained by environmental factors (GRANT, 1993). In addition, according to Spike (1992), when there is low production of solids in herd animals, an alternative would be to search for genetic improvement via use of semen of animals tested with positive characteristics for solids, due to high heritability that this characteristic provides.

The average of protein in milk observed in this study (Table 1) range from $3.06 \%$ in the summer to $3.32 \%$ in the winter. These results are similar to those found by Borges et al. (2009) in Western Santa Catarina. Fagan et al. (2010) analyzed milk production throughout the seasons of the year, also found a significant difference $(\mathrm{P}<0.05)$ in milk protein content. In this study, the average protein content during summer, winter, and spring was $3.04 \%$, while in the fall it was $2.87 \%$. Similar results were also found by Roma Júnior et al. (2009), but with lower variation in different seasons.

The average content of protein (3.20\%) found in this study is similar to those described in Machado, Pereira and Sarries (2000) and by DHIA (2001), but lower than those found in Canada (3.35\%) (FPLQ, 2000), France (3.35\%) (FCL, 2000), Germany (3.42\%) (ADR, 2001), and New Zealand (3.61\%) (NZDG, 2001).

As reported by Wong (1988), the levels of milk protein have low variation $(0.4 \%$ to $0.6 \%)$. The author points out that diet improvements affects milk production more than the percentage of protein in milk. Moreover, Fredeen (1996) noted that nutrition can be responsible for up to $50 \%$ of the milk protein changes and it explains most of the variation of the protein content found in this study, since cows received completely different food throughout the year, from tropical grasses in the summer to temperate in the winter. The higher levels of protein presented by temperate grasses in relation to tropical may have influenced a higher production of protein in milk during the autumn and winter. Noro et al. (2006) found higher levels of protein, fat, and lactose in the winter, attributing this result to feeding with temperate grasses.

The protein content in milk can be influenced by the amino acid profile that reaches the intestine to be absorbed, which in turn depends on the amount of energy and protein intake by animals (NRC, 2001; BAUMAN; GRIINARI, 2003). These could also help to explain, at least in part, the high protein found in the fall and winter seasons, due to the use of pasture composed of temperate grasses.

There were differences $(\mathrm{P}<0.05)$ in SCC of milk from different seasons of the year. The summer period showed the highest rates of SCC, followed by autumn. The lowest SCC values were observed in the winter and spring, with no significant differences ( $\mathrm{P}>0.05$ ) (Table 1). The results ranged from 606.25 to 2631.00 thousands of cells $/ \mathrm{mL}$ of milk on winter and summer, respectively. Allore, Oltenacu and Erb (1997) also reported differences in the SCC related to season and geographical region. Similar results were also found by Leite et al. (2004) and Roma Júnior et al. (2009) on the variation of SCC. The authors attribute the higher average in the summer to stress due to high temperatures exposing animals to a greater number of pathogens and increasing susceptibility to infections and occurrence of mastitis. Also, according to Harmon (1994) some stressors, especially heat, may increase SCC milk.

However, there are many contradictions in the literature regarding SCC in milk from different regions, because the adopted management in dairy production directly affects the quality of milk. Vasconcelos et al. (1997) found no difference in SCC between milk samples collected in summer and winter, in the state of São Paulo. On the other hand, Ostrensky (1999) found in the state of Paraná, Brazil, largest SCC results in the period from November to April when compared to the months of May and October. In the state of Rio Grande do Sul, Noro et al. (2006) found higher SCC in May and Milani 
(2011) observed higher SCC in summer. Another factor that could explain the lower concentration of fat and protein in the summer would be the presence of lipases leukocyte metabolizing fatty acids in milk (AULDIST et al., 1995; BRITO; DIAS, 1998) and leukocyte proteases that could cause a significant reduction on casein (HARMON, 1994; BUENO et al., 2005), which could lead to a reduction in total milk solids that could vary from 3 to $12 \%$.

The data regarding the relation between SCC and the amount of solids in Brazil are still contradictory. According to Pereira et al. (1999) solids tend to decrease with an SCC above 283.000 cells $/ \mathrm{mL}$, whereas Machado, Pereira and Sarries (2000) reports that only values above 500.000 cells $/ \mathrm{mL}$ would cause a decrease on solids in milk. However, our study shows much higher values than the figures quoted, which could suggest that there was a loss in milk composition due to high SCC. Reinforcing this argument, Noro et al. (2006) observed an increase in fat and protein components with an increase in somatic cell counts.

According to Philpot and Nickerson (1991), somatic cells are all cells present in milk, which include cells originating from the blood stream, such as leukocytes and cells of the secretory epithelium desquamation. Thus, the SCC in milk is a valuable tool to assess and monitor subclinical mastitis in the herd, which can cause numerous damages to producers, mainly due to the drop in milk production, medicine expenses, and even cow elimination. Moreover, milk with high SCC, when used for dairy products can cause changes in the quality of the final product, which results in lower industrial production, increased length of clot, and negative changes in sensory quality (LEITNER et al., 2006; KITCHEN, 1981).

As for the TBC, the winter period had the highest scores, followed by spring and summer, which did not differ, and the autumn period that had lower TBC $(\mathrm{P}<0.05)$ (Table 1). The TBC in milk is a test used to evaluate milk quality, and its result provides an indication of hygiene employed during milk production and handling (SCHAIK et al., 2005). Thus, high bacterial counts indicate failures in cleaning the equipment, milking hygiene, or problems on milk refrigeration (VALLIN et al., 2009).

The TBC had higher mean values and periodic variations more pronounced than the SCC. Furthermore, it is possible to note that TBC was higher in the colder seasons of the year, when humidity is intense in the Western of Santa Catarina. In periods of increased moisture, there is greater difficulty in animal handling and errors may occur in the complete removal of sediment and mud stuck to animal body. In the study area, during winter and spring there are long raining periods which could explain the higher TBC in these seasons.

Even with the high values found for TBC in this study, according to Brito et al. (2007) the reduction of TBC can be achieved in a short period of time since hygiene procedures are followed in the milking process, such as equipment cleaning that come into contact with milk and the correct storage of milk immediately after milking at $4{ }^{\circ} \mathrm{C}$. The same authors found a reduction in the bacterial count of 88.300 to $74.000 \mathrm{CFU} / \mathrm{mL}$ before and after, respectively, the adoption of hygiene practices during milking and equipment held for three days in ten properties of seven Brazilian states (Pernambuco, Sergipe, Alagoas, Minas Gerais, São Paulo and Rio Grande do $\mathrm{Sul}$ ), which corresponded to a reduction of $91.6 \%$ in the values of TBC.

Corroborating with these results, Roma Júnior et al. (2009) associated the lowest values of TBC to autumn, a period of low rates of precipitation in the Southeast, which somehow also shows that TBC is more affected by rainfall than actually with the season. Already Borges et al. (2009) found no clear relation between TBC and the seasons of the year. In a study conducted in Chile with small milk producers, the average value for TBC was 332.000 CFU/mL (SCHAIK et al., 2005), lower annual average obtained in the present study. 
The results presented in Table 2 indicate that $4.4 \%$ and $2.6 \%$ of the samples have fat content lower than $3.0 \%$ in summer and spring, respectively, and therefore would be below the levels recommended by IN 51 (BRASIL, 2002). In the other periods of the year, only a small amount of milk samples would be out of the recommended standard (maximum of $0.7 \%$ in the winter).

As the protein content, a great amount of milk produced would be out of the standards required by law, regardless of the season studied. However, during the summer up to $22.4 \%$ samples had protein content below $2.9 \%$, associated with the quality of tropical pastures, as mentioned earlier.

In relation to the $\mathrm{SCC}$, according to the season evaluated, 28 to $41.8 \%$ of the samples did not meet the standard of IN 51 in place during the studied period and this percentage would rise to 41.6 to
$56.1 \%$ according to the new standards set by IN 62 (Table 2). It can be inferred that, despite discussions on how to improve milk quality, major challenges still exist and there is a need to establish some strategies to decrease the SCC, such as teat hygiene and, above all, the protocol for mastitis treatment.

As for TBC, results highlighted that according to the season, between 59.6 and $80.4 \%$ of the samples did not meet the standards of IN $51(<750000$ CFU/ $\mathrm{mL})$ in effect at the time of collection. Considering the current limit recommended by IN $62(<600.000$ $\mathrm{CFU} / \mathrm{mL}$ ), this percentage would increase from 64.5 to $85.9 \%$, depending on the season. In Chile, the producers are penalized when milk TBC is higher than 100.000 CFU/mL (SCHAIK et al., 2005), limit that would be inforced in Brazil in 2012 according to IN 51, but the limit was revised and amended to 600.000 CFU/mL by IN 62 (BRASIL, 2002).

Table 2. Percentage of milk samples in accordance with the limits set by IN 51 and IN 62 at different times of the year, in dairy cattle in Western Santa Catarina-Brazil.

\begin{tabular}{lcllll}
\hline \multirow{2}{*}{ Variable } & \multirow{2}{*}{ Reference } & \multicolumn{4}{c}{ Samples (\%) according to season } \\
\cline { 3 - 6 } & & Summer & Autumn & Winter & Spring \\
\hline \multirow{2}{*}{ Fat $(\%)$} & $<3 \%$ & 4,4 & 0,1 & 0,7 & 2,6 \\
& $\geq 3 \%$ & 95,6 & 99,9 & 99,3 & 97,4 \\
\hline \multirow{2}{*}{ Protein (\%) } & $<2,9 \%$ & 22,4 & 4,8 & 2,6 & 10,0 \\
& $\geq 2,9 \%$ & 77,6 & 95,2 & 97,4 & 90,0 \\
\hline \multirow{2}{*}{ SCC (thousands cell/mL) } & $<600$ & 43,9 & 49,0 & 58,3 & 56,9 \\
& From 600 a 750 & 14,3 & 12,5 & 13,2 & 12,3 \\
& $\geq 750$ & 41,8 & 38,5 & 28,5 & 30,8 \\
\multirow{2}{*}{ TBC (thousands UFC/mL) } & $<600$ & 14,1 & 25,0 & 35,5 & 25,5 \\
& From 600 a 750 & 5,5 & 6,0 & 4,9 & 6,8 \\
& $\geq 750$ & 80,4 & 69,0 & 59,6 & 67,7 \\
\hline
\end{tabular}

According to IN 51: a minimum limit of $3.0 \%$ for fat and $2.9 \%$ for protein; SCC maximum of 750.000 cells $/ \mathrm{mL}$ of milk and TBC maximum of $750.000 \mathrm{CFU} / \mathrm{mL}$ of milk. According to IN 62: SCC maximum of $600.000 \mathrm{cells} / \mathrm{mL}$ of milk and TBC maximum of $600.000 \mathrm{CFU} / \mathrm{mL}$ of milk.

Source: Elaboration of the authors.

Delavechia, Tizziani and Simioni (2011a, 2011b) found on 29 farms in the Western of Santa Catarina State that $6.9,10.3,13.8$, and $13.8 \%$ of producers did not meet the standards set by IN 51 at the time (summer) regarding fat, protein, SCC, and TBC, respectively. Similarly, Auler, Verona and Sobczak (2012) based on the data from September to November 2008, on 28 farms in Bela Vista, Santa Catarina State, found that $54.76 \%$ of producers do not meet the standards of TBC and $22.61 \%$ do not meet SCC standards set by IN 51.

Winck and Thaler Neto (2009) evaluated 166 properties from Midwest and Upper Itajai Valley in 
Santa Catarina State and observed that most dairy farms were suited to the IN 51 for SCC, but not for TBC. According to milk samples analyzed in the Milk Quality Laboratory of Embrapa Southeast region, from January 2007 to June 2008, 20.2 and $58.3 \%$ did not meet the threshold as recommended by IN 51 regarding $\mathrm{SCC}$ and $\mathrm{TBC}$, respectively (SOUZA et al., 2008). These percentages are similar to those obtained in this work during the winter period, but lower than for the same seasons evaluated.

Data of 326 samples of milk from the Northwest Mesoregion of Rio Grande do Sul State, in the period of October 2007 to September 2010, Milani (2011) found that $8.97,14.25,38.19$, and $77.08 \%$ of the samples did not meet IN 51 regarding fat, protein, SCC and TBC, respectively, similarly to those showed here.
In Brazil, the programs that pay for milk quality have been used by several dairy companies where they link the payment to the producer to some aspects related to milk quality. Allied to this, the National Milk Quality Improvement, supported by IN 51 and IN 62 of the Ministry of Agriculture and Supply (MAPA), aims to encourage producers to seek improvement of its products, which would result in better industrial performance, bonus by generating high-quality milk, or milk penalties for low quality (ROMA JÚNIOR et al., 2009). Considering that the evaluated region is especially composed by family farming, the impact of penalties significantly affects the properties economically. Table 3 shows that $72.5 \%$ and $63.5 \%$ of the farmers usually receive a bonus for milk with good fat and protein levels, respectively.

Table 3. Impact on the price paid to the producer (\%) (penalty, no bonus, bonus) according to the levels of fat and protein, in dairy cattle in Western Santa Catarina-Brazil.

\begin{tabular}{|c|c|c|c|c|c|c|c|}
\hline \multicolumn{4}{|c|}{ Fat } & \multicolumn{4}{|c|}{ Protein } \\
\hline $\begin{array}{c}\text { Classes of fat } \\
(\%)\end{array}$ & $\begin{array}{l}\text { Impact on the } \\
\text { to the produ }\end{array}$ & $\begin{array}{l}\text { e paid } \\
(\%)\end{array}$ & Producers $(\%)$ & $\begin{array}{l}\text { Classes of } \\
\text { Protein }(\%)\end{array}$ & $\begin{array}{r}\text { Impact on } t \\
\text { paid to the } p \\
(\%)\end{array}$ & $\begin{array}{l}\text { rice } \\
\text { ucer }\end{array}$ & Producers $(\%)$ \\
\hline $0.00-2.99$ & \multirow{4}{*}{ Penalty } & 1.00 & 4.4 & $0.00-2.80$ & \multirow{4}{*}{ Penalty } & 1.00 & 5.5 \\
\hline $3.00-3.20$ & & 0.75 & 4.4 & $2.81-2,90$ & & 0.75 & 6.7 \\
\hline $3.21-3.30$ & & 0.50 & 3.5 & $2,91-3,00$ & & 0.50 & 10.5 \\
\hline $3.31-3.40$ & & 0.25 & 4,7 & $3,01-3,05$ & & 0.25 & 6.1 \\
\hline $3.41-3.55$ & No bonus & 0.00 & 8.5 & $3.06-3.10$ & No bonus & 0.00 & 7.1 \\
\hline $3.56-3.70$ & \multirow{4}{*}{ Bonus } & 0.25 & 11.0 & $3.11-3.15$ & \multirow{4}{*}{ Bonus } & 0.25 & 8.2 \\
\hline $3.71-3.85$ & & 0.50 & 11.7 & $3.16-3.20$ & & 0.50 & 8.0 \\
\hline $3.86-3.99$ & & 0.75 & 9.9 & $3.21-3.29$ & & 0.75 & 13.4 \\
\hline $4.00-5.50$ & & 1.00 & 39.9 & $3.30-3.99$ & & 1.00 & 33.9 \\
\hline 5.51 added & Neutral & 0.00 & 2.0 & 4.00 added & Neutral & 0.00 & 0.7 \\
\hline
\end{tabular}

Source: Elaboration of the authors.

Milk with lower fat and protein content is less efficient to the dairy industry to produce dairy products due to a lower yield of products. However, from the viewpoint of industrialization due to the high fat levels encountered in most samples from this study, milk with higher total solids content leads to a higher yield of cheese, especially the fat and the protein casein (STUBBS; ABUD; BENCINI, 2009). Regarding the SCC, $41.5 \%$ of producers would suffer reduced milk price and in the item TBC, $76.7 \%$ of the producers would have negative impact (Tables 4 and 5). This reflects that the main 
problem of milk quality is associated with issues of hygiene and sanitary production.

Data analysis shows the importance of defining a criteria to pay a bonus or to penalize the producer. It is also noticed that the main factor reducing the price is linked to the hygiene practices by the producer, a factor that deserves greater attention with more training programs and technical assistance.

Table 4. Distribution of farmers according to the impact on the price of milk (penalty, no bonus, bonus) according to the levels of somatic cell count, in dairy cattle in Western Santa Catarina-Brazil.

\begin{tabular}{lcccc}
$\begin{array}{l}\text { Classes of SCC (thousands of } \\
\text { cells/mL) }\end{array}$ & $\begin{array}{c}\text { Impact on the price paid to the } \\
\text { producer (\%) }\end{array}$ & Producers (\%) & Cumulative (\%) \\
\hline $0.00-150$ & Bonus & 4.0 & 4.0 & \\
$151-300$ & & 2.0 & 12.6 & 50.0 \\
$301-450$ & & 1.0 & 17.0 & \\
$451-600$ & No bonus & 0.5 & 16.4 & 8.5 \\
\hline $601-700$ & & 0.0 & 8.5 & 41.5 \\
$701-800$ & Penalty & 0.5 & 7.5 & \\
$801-900$ & & 1.0 & 6.1 & \\
$901-999$ & 1.5 & 4.4 & 23.5 \\
1000 or more & & 2.0 & &
\end{tabular}

Source: Elaboration of the authors.

Table 5. Distribution of farmers according to the impact on the price of milk (penalty, no bonus, bonus) according to the levels of TBC, in dairy cattle in Western Santa Catarina-Brazil.

\begin{tabular}{|c|c|c|c|c|}
\hline $\begin{array}{l}\text { Classes of TBC (thousands of } \\
\text { UFC } / \mathrm{mL} \text { ) }\end{array}$ & \multicolumn{2}{|c|}{$\begin{array}{c}\text { Impact on the price paid to the } \\
\text { producer }(\%)\end{array}$} & Producers $(\%)$ & Cumulative (\%) \\
\hline $0.00-100$ & \multirow{6}{*}{ Bonus } & 6.0 & 3.3 & \multirow{6}{*}{19.4} \\
\hline $101-200$ & & 4.0 & 4.0 & \\
\hline $201-300$ & & 3.0 & 4.5 & \\
\hline $301-400$ & & 2.0 & 4.0 & \\
\hline $401-450$ & & 1.0 & 1.8 & \\
\hline $451-500$ & & 0.5 & 1.8 & \\
\hline $501-600$ & No bonus & 0.0 & 3.9 & 3.9 \\
\hline $601-700$ & \multirow{6}{*}{ Penalty } & 0.5 & 3.5 & \multirow{6}{*}{76.7} \\
\hline $701-800$ & & 1.0 & 3.6 & \\
\hline $801-850$ & & 1.5 & 1.7 & \\
\hline $851-900$ & & 2.0 & 1.6 & \\
\hline $901-999$ & & 2.5 & 3.1 & \\
\hline 1000 or more & & 3.0 & 63.2 & \\
\hline
\end{tabular}

Source: Elaboration of the authors. 


\section{Conclusions}

Milk quality parameters evaluated showed significant variations over the seasons, noticed that the fat content was higher in the fall, the TBC and protein were higher in winter and SCC showed the highest rates in the summer. Changes in fat and protein are caused mainly by changes in the type of pasture fed to the animals. Periods of high humidity may hamper cleaning processes resulting in higher TBC, whereas heat stress in summer provides higher levels of SCC.

The main problem of milk quality is associated with TBC when considered the standards established by IN 51 and IN 62, where highest counts were observed in the winter, and the summer time showed the highest percentage of samples out of the standards.

Considering the payment system according to milk quality, chemical composition results in better prices for the majority of producers, and TBC is primarily responsible for penalties to the producers.

\section{References}

ARBEITSGEMEINSCHAFT

DEUTSCHER RINDERZUCHTER - ADR. Bonn/Deutschland: ADR, 2001. Available at: <http://www.adr-web.de $>$. Accessed at: 20 ago. 2012.

ALlORE, G. H.; OlTENACU, P. A.; ERB, H. N. Effects of season, herd size, and geographic region on the composition and quality of milk in the Northeast. Journal of Dairy Science, Champaing, v. 80, n. 11, p. 3040-3049, 1997.

AULDIST, M. J.; COATS, S.; ROGERS, G. L.; McDOWELL, G. H. Changes in the composition of milk from healthy and mastitis dairy cows during the lactation cycle. Australian Journal of Experimental Agriculture, Collingwood, v. 35, n. 4, p. 427-436, 1995.

AULER, A. C.; VERONA, R. B.; SOBCZAK, M. F. Comparação da qualidade do leite produzido em pequenas propriedades rurais do município de Dionísio Cerqueira com a Instrução Normativa 51. In: CONGRESSO BRASILEIRO DE PRODUÇÃO ANIMAL SUSTENTÁVEL, 2., 2012, Chapecó, Anais... Chapecó: Universidade do Estado de Santa Catarina, 2012. CD-ROM.
BAUMAN, D. E.; GRIINARI, J. M. Nutritional regulation of milk synthesis. Annual Review of Nutrition, Palo Alto, v. 23, n. 5, p. 223-237, 2003.

BAUMGARD, L. H.; MATITASHVILI, E.; CORL, B. A.; DWYER, D. A.; BAUMAN, D. E. Trans-10, cis-12 conjugated linoleic acid decreases lipogenic rates and expression of genes involved in milk lipid synthesis in dairy cows. Journal of Dairy Science, Champaing, v. 85, n. 9, p. 2155-2163, 2002.

BORGES, K. A.; REICHERT, S.; ZANELA, M. B.; FISCHER, V. Avaliação da qualidade do leite de propriedades da região do Vale do Taquari no estado do Rio Grande do Sul. Acta Scientiae Veterinariae, Porto Alegre, v. 37, n. 1, p. 39-44, 2009.

BRASIL. Ministério da Agricultura Pecuária e Abastecimento. Instrução Normativa $\mathrm{N}^{\circ} 51$, de 18 de setembro de 2002. Regulamentos técnicos de produção, identidade e qualidade do leite tipo A, do leite tipo B, do leite tipo $\mathrm{C}$, do leite pasteurizado e do leite cru refrigerado e o regulamento técnico da coleta de leite cru refrigerado e seu transporte a granel. Diário Oficial [da] União, Brasília, DF, 20 set. 2002, Seção 1, p. 13-22, 2002.

Ministério da Agricultura Pecuária e Abastecimento. Instrução Normativa $\mathrm{N}^{\circ} 22$, de 07 de julho de 2009. Estabelece as normas técnicas para utilização de tanques comunitários visando à conservação da qualidade do leite cru, proveniente de diferentes propriedades rurais. Diário Oficial [da] União, Brasília, DF, 08 jul. 2009, Seção 1, p. 8-8, 2009.

Ministério da Agricultura Pecuária e Abastecimento. Instrução Normativa $\mathrm{N}^{\circ} 62$, de 29 de dezembro de 2011. Regulamento técnico de produção, identidade e qualidade do leite tipo A, o regulamento técnico de identidade e qualidade de leite cru refrigerado, o regulamento técnico de identidade e qualidade de leite pasteurizado e o regulamento técnico da coleta de leite cru refrigerado e seu transporte a granel. Diário Oficial [da] União, Brasília, DF, 30 dez. 2011, Seção 1, p. 6-11, 2011.

BRITO, J. R. F.; BRITO, M. A. V. P.; SOUZA, G. N.; MORAES, L. C. D.; ARCURI, E. F.; LANGE, C.; FÁBIO, H. D. Avaliação da eficiência do "Kit Embrapa Ordenha Manual" para melhorar a qualidade microbiológica do leite em pequenas propriedades de quatro regiões brasileiras. In: CONGRESSO INTERNACIONAL DO LEITE, 6., 2007, Resende. Anais... Juiz de Fora: Embrapa Gado de Leite, 2007. CD ROM.

BRITO, J. R. F.; DIAS, J. C. A qualidade do leite. Juiz de Fora: Embrapa. 1998. 98 p. 
BUENO, V. F. F.; MESQUITA, A. J.; NICOLAU, E. S.; OLIVEIRA, A. N.; OLIVEIRA, J. P.; NEVES, R. B. S.; MANSUR, J. R. G.; THOMAZ, L. W. Contagem celular somática: relação com a composição centesimal do leite e no período do ano no Estado de Goiás. Ciência Rural, Santa Maria, v. 35, n. 4, p. 848-854, 2005.

DAIRY HERD IMPROVEMENT ANALYSIS - DHIA. Annual summaries. Califórnia: DHIA, 2001. Available at: $<$ http://www.cdhia.org/annual summaries $>$. Accessed at: 30 ago. 2012.

DELAVECHIA, P. R.; TIZZIANI, R.; SIMIONI, F. J. Qualidade do leite: teor de gordura e proteína. Jornal Sul Brasil - Caderno Rural, Chapecó, ed. 64, p. 3-3, 2011 a.

Qualidade do leite: presença de bactérias e células somáticas. Jornal Sul Brasil - Caderno Rural, Chapecó, ed. 65, p. 3-3, 2011 b.

DURÃES, M. S.; FREITAS, A. R.; COSTA, C. N. Influência da raça e do touro na qualidade do leite. Revista Balde Branco, São Paulo, v. 37, n. 443, p. 36-42, 2001.

FAGAN, E. P.; JOBIM, C. C.; CALIXTO JÚNIOR, M.; SILVA, M. S.; SANTOS, T. Fatores ambientais e de manejo sobre a composição química do leite em granjas do Estado do Paraná, Brasil. Acta Scientiarum, Maringá, v. 32, n. 3, p. 309-316, 2010.

FRANCE CONTROLE LAITIER ET L'INSTITUT DE L'ELEVAGE - FCL. Rapport annuel. 2000. Disponível em: <http://www.france-controle-laitier-fr $>$. Accessed at: 30 ago. 2012.

FONSECA, L. F. L.; SANTOS, M. V. Qualidade do leite e controle da mastite. São Paulo: Lemos Editorial, 2000. $175 \mathrm{p}$.

FEDERACION DES PRODUCTEURS LAITIERS DU QUEBEC - FPLQ. Rapport annuel. 2000. Available at: $<$ http://www.lait.org>. Acesso em: 30 ago. 2012.

FREDEEN, A. H. Considerations in the nutritional modification of milk composition. Animal Feed Science and Technology, Amsterdam, v. 59, n. 1, p. 185-197, 1996.

GOMES, D. I.; ALVES, K. S.; OLIVEIRA, L. R. S.; VÉRAS, R. M. L.; BARCELOS, S. S.; BARBOSA, C. V. Qualidade do leite bovino oriundo de diferentes propriedades rurais na região sudeste do Pará, Brasil. Revista de Ciências Agrárias, Belém, v. 54, n. 2, p. 165 171, 2011.

GONZÁLEZ, F. H. D. Pode o leite refletir o metabolismo da vaca? In: DÜRR, J. W.; CARVALHO, M. P.; SANTOS, M. V. dos (Org.). O compromisso com a qualidade do leite no Brasil. Passo Fundo: UPF Editora, 2004. p. 195209.
GRANT, R. J. Feeding to maximize milk solids. Lincoln: Agricultural publication, University of Nebraska, 1993. Available at: $<\mathrm{http}: / /$ extension.missouri.edu/publications/ DisplayPrinterFriendlyPub.aspx?P=G3110>. Accessed at: 30 ago. 2012.

GREEN, M. J.; BRADLEY, A. J.; NEWTON, H.; BROWNE, W. J. Seasonal variation of bulk milk somatic cell counts in UK dairy herds: investigations of the summer rise. Preventive Veterinary Medicine, Pepperell, n. 74, n. 4, p. 293-308, 2006.

HARMON, R. J. Physiology of mastitis and factors affecting somatic cell counts. Journal of Dairy Science, Champaing, v. 77, n. 7, p. 2103-2112, 1994.

INSTITUTO BRASILEIRO DE GEOGRAFIA E ESTATÍSTICA- IBGE. Produção agrícola municipal (PAM). Brasil: Abril, 2010. Disponível em: <http://www. sidra.ibge.gov.br>. Acesso em: 10 dez. 2011.

INTERNATIONAL DAIRY FEDERATION - IDF. Milk: enumeration of somatic cells. Guidance on the operation of fluoro-opto-electronic counters. IDF Standard 1482(E). Brussels: International Dairy Federation, 2006. 13 p.

Milk: quantitative determination of bacteriological quality. IDF Standard 196:2004(E). Brussels: International Dairy Federation, 2004. 13 p.

Whole milk: determination of milkfat, protein and lactose content. Guidance on the operation of midinfrared instruments. IDF Standard 141C:2000. Brussels: International Dairy Federation, 2000. 15 p.

KITCHEN, B. J. Review of the progress of dairy science: bovine mastitis - milk compositional changes and related diagnostics test. Journal of Dairy Research, Champaing, v. 48, n. 1, p. 167-188, 1981.

LEITE, M. C. P.; RIBAS, N. P.; MONARDES, H. G.; ARCE, J. E.; ANDRADE, U. V. C. Contagem de células somáticas em amostras de leite. Revista Brasileira de Zootecnia, Viçosa, v. 33, n. 5, p. 1303-1308, 2004.

LEITNER, G.; KRIFUCKS, O.; MERIN, U.; LAVI, Y.; SILANIKOVE, N. Interactions between bacteria type, proteolysis of casein and physico-chemical properties of bovine milk. International Dairy Journal, Québec, v. 16, n. 6, p. 48-654, 2006.

LOOPER, M.; STOKES, S. R.; WALDNER, D. N.; JORDAN, E. R. Managing milk composition: evaluating herd potential. Oklahoma Cooperative Extension Service. College of Agriculture and Home Economics. New Mexico State University, 2001. 100 p.

MACHADO, P. F.; PEREIRA, A. R.; SARRIES, G. A. Composição do leite de tanques de rebanhos brasileiros 
distribuídos segundo sua contagem de células somáticas. Revista Brasileira de Zootecnia, Viçosa, v. 29, n. 6, p. 1883-1886, 2000.

MILANI, M. P. Qualidade do leite em diferentes sistemas de produção, anos e estações climáticas no Noroeste do Rio Grande do Sul. 2011. Dissertação (Mestrado em Ciência e Tecnologia dos Alimentos) - Universidade Federal de Santa Maria, Santa Maria.

NAJAFI, M. N.; MORTAZA, S. A.; KOOCHEKI, A.; KHORAMI, J.; REKIK, B. Fat and protein contents, acidity and somatic cell counts in bulk milk of Holstein cows in the Khorasan Razavi Province, Iran. International Journal of Dairy Technology, Huntingdon, v. 1, n. 62, p. 19-26, 2009.

NORO, G.; GONZÁLEZ, F. H. D.; CAMPOS, R.; DÜRR, J. W. Fatores ambientais que afetam a produção e a composição do leite em rebanhos assistidos por cooperativas no Rio Grande do Sul. Revista Brasileira de Zootecnia, Viçosa, v. 35, 1129-1135, 2006. Suplemento.

NATIONAL RESEARCH COUNCIL - NRC. Nutrient requirements of dairy cattle. 7. ed. rev. Washington, 2001. $381 \mathrm{p}$.

NEW ZEALAND DAIRY GROUP - NZDG. Milk quality publications. 2001. Available at: <http://www. nzdairy.co.nz $>$. Accessed at: 30 ago. 2012.

OMETTO, J. C. Bioclimatologia vegetal. São Paulo: Ceres, 1981. $421 \mathrm{p}$.

OSTRENSKY, A. Efeitos de ambiente sobre a contagem de células somáticas no leite de vacas da raça holandesa no Paraná. 1999. Dissertação (Mestrado em Ciências Veterinárias) - Setor de Ciências Agrárias, Universidade Federal do Paraná, Curitiba.

PAIVA, C. A. V.; CERQUEIRA, M. M. O. P.; SOUZA, M. R. S.; LANA, A. M. Q. Evolução anual da qualidade do leite cru refrigerado processado em uma indústria de Minas Gerais. Arquivo Brasileiro de Medicina Veterinária e Zootecnia, Belo Horizonte, v. 64, n. 2, p. 471-478, 2012.

PEREIRA, A. R.; SILVA, L. F. P.; MOLON, L. K.; MACHADO, P. F.; BARANCELLI, G. Efeito do nível de células somáticas sobre os constituintes do leite I - gordura e proteína. Brazilian Journal Veterinary Research and Animal Science, Pirassununga, v. 36, n. 3, p. 429-433, 1999.

PHILPOT, W.; NICKERSON, S. C. Mastitis: counter attack - a strategy to combat mastitis. Illinois: Babson Brothers Co., 1991. 150 p.

REIS, G. L.; ALVES, A. A.; LANA, A. M. Q.; COELHO, S. G.; SOUZA, M. R.; CERQUEIRA, M. M. O. P.;
PENNA, C. F. A. M.; MENDES, E. D. M. Procedimentos de coleta de leite cru individual e sua relação com a composição físico química e a contagem de células somáticas. Ciência Rural, Santa Maria, v. 37, n. 4, p. 1134-1138, 2007.

RIBAS, N. P.; HARTMANN, W.; MONARDES, H. G.; ANDRADE, V. U. C. Sólidos totais do leite em amostras de tanque nos estados do Paraná, Santa Catarina e São Paulo. Revista Brasileira de Zootecnia, Viçosa, v. 33, n. 6, p. 2343-2350, 2004. Suplemento 3.

RIBAS, N. P.; SANTOS, C. J.; NUNEZ, C. M. GERVÁRIO, V. J.; OLIVEIRA, G. R.; FRANCO, S. G. Estudo da produção de leite, gordura e percentagem de gordura em vacas da raça Holandesa, importadas do Canadá. Revista do Setor de Ciências Agrárias, Curitiba, v. 7, n. 12, p. 97-104, 1985.

ROMA JÚNIOR, L. C.; MONTOYA, J. F. G.; MARTINS, T. T.; CASSOLI, L. D.; MACHADO, P. F. Sazonalidade do teor de proteína e outros componentes do leite e sua relação com programa de pagamento por qualidade. Arquivo Brasileiro de Medicina Veterinária e Zootecnia, Belo Horizonte, v. 61, n. 6, p. 1411-1418, 2009.

SANTOS, O. V.; PEREIRA, L. B.; SIMIONI, F. J.; MATTEI, L. Panorama e relocalização geográfica da produção de leite em Santa Catarina. In: PEREIRA, L. B.; CÁRIO, S. A. F.; KOEHLER, M. (Org.). Padrão produtivo e dinâmica econômica competitiva: estudo sobre setores selecionados em Santa Catarina. Florianópolis: Imprensa Universitária da UFSC, 2001, p. 177-186.

SAS INSTITUTE. Procedures guide of computers. $6^{\text {th }}$ ed. New York, 1999. v. 3, 373 p.

SCHAIK, G.; GREEN, L. E.; GUZMÁN, D.; ESPARZA, H.; TADICH, N. Risk factors for bulk milk somatic cell counts and total bacterial counts in smallholder dairy farms in the 10th region of Chile. Preventive Veterinary Medicine, Pepperell, v. 67, n. 1, p. 1-17, 2005.

SOUZA, G. N.; BRITO, M. A. V. P.; LANGE, C. C.; FARIA, C. G.; MORAES, L. C. D.; BRITO, J. R. F. Qualidade do leite de rebanhos bovinos localizados na Região Sudeste: Espírito Santo, Minas Gerais, Rio de janeiro - janeiro/2007 a junho/2008. In: COMGRESSO BRASILEIRO DE QUALIDADE DO LEITE, 3., 2008, Recife. Anais... Recife: CCS Gráfica e Editora, 2008. v. 3. p. 11-21.

SPIKE, P. W. Breeding programs for traits other than milk production. Athens: University of Ohio, 1992. Available at: $<$ http://www.ansci.cornell.edu/ogibin/db2>. Accessed at: 30 ago. 2012. 
STUBBS, A.; ABUD, G.; BENCINI, R. Dairy sheep manual. Kingston: Farm Management Guidelines, RIRDC, 2009. 69 p.

VALLIN, V. M.; BELOTI, V.; BATTAGLINI, A. P. P.; TAMANINI, R.; FAGNANI, R.; ANGELA, H. L.; SILVA, L. C. C. Melhoria da qualidade do leite a partir da implantação de boas práticas de higiene na ordenha em 19 municípios da região central do Paraná. Sêmina: Ciências Agrárias, Londrina, v. 30, n. 1, p. 181-188, 2009.
VASCONCELOS, C. G. C.; NADER FILHO, A.; AMARAL, L. A.; PEREIRA, G. T. Influência da estação do ano, do estádio de lactação e da hora da ordenha sobre o número de células somáticas do leite bovino. Arquivo Brasileiro de Medicina Veterinária e Zootecnia, Belo Horizonte, v. 49, n. 4, p. 483-491, 1997.

WINCK, C. A.; THALER NETO, A. Diagnóstico da adequação de propriedades leiteiras em Santa Catarina às normas brasileiras de qualidade do leite. Revista de Ciências Agroveterinárias, Lages, v. 8, n. 2, p. 164-172, 2009.

WONG, N. P. Fundamentals of dairy chemistry. 30. ed. New York: Van Nostrand Runhold Company, 1988. 346 p. 